\title{
A Flowing Reputation
}

Victor Becerra

I got up to get ready for breakfast. I felt tired. I had not been sleeping well for the last few weeks. Ever since my cell had been "trashed" by the I.S.U. (Institutional Security Unit), I had been feeling other prisoners looking at me differently. Even worse, guards were treating me with animosity. They are supposed to be professional and treat all prisoners with dignity and respect (for the money they get paid, it is the least they could do), but most are far from professional.

After I came back from breakfast, I read a book for one of the classes I was taking, wrote some letters and kept busy until I had to go to work. I was at work for less than 20 minutes before my supervisor came and told me that I had to report to my wing guard, because he had called for me to take a "random" mandatory drug test (urine test). How random can they be if this was my third test in six months? I have never used any illegal drugs and I keep getting tested, while active, well-known drug users never get tested. I am sure they have a database of who has been tested and who has not. Perhaps the reason certain individuals never get tested is because some corrupt guards are the ones bringing in the drugs.

So, I went back to my wing. As I got closer to the office, I overheard the two wing guards having a conversation, "I can get 1000k with overtime" one of them said proudly. The office door was open, but I knocked to let them know I was there. When the guard saw me, I said, "I was told you called for me". "Are you ready to piss?" was his quick, sharp response. "Because I don't have the fucking time to wait for your fucking ass to feel like fucking pissing and shit" he continued.

I remained quiet, trying to figure out the reason for his deep anger. Sadly, his attitude did not surprise me. It was normal for him. One day I was in the dayroom and I witnessed what sounded like a prisoner argument right before a fight. I heard a lot of offensive, vulgar insults getting louder and louder. When I turned to see who was yelling like that, I discovered it was that same guard threatening to beat up a prisoner. I was surprised because the guard sounded like a common street thug. On the other hand, the prisoner kept his cool but also kept his arms in a defensive position, just in case the guard followed through with his threats. In a way, I felt sorry for the guard. I mean, he is free to go home, so why the bad attitude? If my job ever made me hate life that much, I would simply quit or at least take a few days off, but this guy was here all day and sometimes he even worked double shifts. I am not 
saying he worked a couple hours overtime. I am saying he worked two eight hour shift in a row on a regular basis. Life is too short to be mad at everything.

When he had finished his cursing, I said, "You called me for a test. I came right away because I'm ready". "Okay, get ready. Wait for me in the fucking restroom", he responded. The single restroom/mop room was a 2' x 9' common area for over 300 prisoners to use when they were not in their cells, and consisted of one toilet at the back end, one floor sink to wash the dirty mops in by the entrance and a rack on which to hang six wet, stinky mops on the side wall. When I walked into the restroom, the first thing I noticed was a foul smell and water all over the floor. The barred windows were covered with plywood, so there was no air circulation, which made the smell of urine worse. So I got out and waited outside, away from the door.

A second guard approached me and told me to get in the restroom. Then he told me to remove my pants and my shirt. I told him to let me out of the restroom to take off my pants. I did not want my pants to soak the restroom "juices" off the floor. The guard did not seem too happy, but allowed me to take my pants off outside. I hung my state-issued blue pants and shirt on a gate outside, and walked back into the restroom, ready for the test. The guard handed me some purple latex gloves and told me to put them on. I guess they did not want me to touch my own penis with my own hands.

I asked the guard for the test container, but he said we needed to wait for his partner, the one with the eloquent speech. "Do you need two of you to watch me urinate?" I asked. "Yeah, that's how we have to do it" he retorted. I wondered if all of this was because of my recent encounter with the Security Unit.

So, there we were, he standing at the door looking at me and I standing in front of the toilet wearing a white T-shirt, white boxers, white socks, boots, and a pair of stylish purple latex gloves. The guard was staring at me, watching me as if I would take off running to avoid being tested. Where would I go? This was ridiculous!

After about five minutes of standing there, taking in the sour smell of prisoner urine on the floor, I told the guard that I would wait for his partner outside. So, I got out of the small, smelly torture chamber. A couple more minutes passed and I kept waiting, so I decided to put on my pants so I would not be standing in the dayroom wearing only my boxers. Five minutes later, the other guard finally arrived. He was carrying what appeared to be a $4 \mathrm{oz}$. urine container inside a sealed plastic bag, and two pre-printed matching sticker labels, one to go around the cup and the other to seal the lid to the cup so that the urine sample did not get mixed up with someone else's urine. 
"Okay, get in the fucking restroom!" he barked. I proceeded to take off my pants right there. When he saw me, he yelled again, "What the fuck are you doing? Get in the restroom first!" I explained to him that I did not want to mop the floor with my pants. He did not like it and continued yelling and cursing. He kept at it until I got inside the restroom.

Once inside, he told me to take off my T-shirt too. "Why?" I asked as I lifted my T-shirt thinking that that would suffice, but he insisted I needed to take my T-shirt completely off. "You're gonna be there watching me urinate into the cup, right? Why do you want my T-shirt off?" It did not make sense to me, but he insisted. So, I walked out of the restroom again to take off my T-shirt to hang it with my shirt and pants. Once again, the guard started yelling and cursing. Then, I also took off my socks. I did not want to go in and have to come back out once again. When he noticed I was taking off my socks, he yelled, "You don't have to take off your socks! Come on!" But I was already done.

So, I walked inside the restroom once again. This time, I was only wearing my white boxers, my brown leather work-boots and the fancy latex purple gloves. He handed me the plastic container and told me to go ahead and piss in it. I unscrewed the lid and turned around to urinate, but right away he yelled, "No! No! I need to see you pissing in it". "So, what was the point of taking off my shirt and pants if you're gonna be looking at my penis urinate inside the cup? It doesn't make sense". They stayed quiet. They knew I was right.

At that time, I was getting tired of their lack of common sense and I realized they did not care so much about the drug test. What they really wanted to do was humiliate me. Even though they had the authority to make me take that test, I would not give them the satisfaction of reacting in the way they wanted me to.

So, since they wanted to see me urinate into the cup, I confidently pulled my boxers all the way down to my knees, spreading my legs so that my boxers would not fall to the floor, and walked four feet towards them (like a penguin). They took a step back, unsure of my intentions. Then, I put my penis inside the cup, right in front of them so they could see me better, since they seemed so eager to see the flow of my urine filling up the cup. When I filled the cup up to the rim, they told me to put the lid on. I did and took off my gloves. "No! What are you doing?!? Keep the gloves on! You need to rinse the cup in the sink! Fuck! I need to get you another pair of gloves" he exclaimed pissed off. I stopped him. "I don't need gloves to rinse the cup. 
The cup is clean, plus it's my own urine". Then I added, "Plus, I couldn't feel anything with the gloves anyway".

Grabbing the container, I rinsed it with cold water. When I was done, the guard handed me a couple of paper towels and told me to dry it off. When I finished, he took the container back. At this time, my boxers were still down to my knees, but I did not care. I stood right in front of him and placed my hands on my waist, waiting for him to tell me what else he wanted me to do.

As I stood there, he peeled off one of the pre-printed name and serial number sticker labels and stuck it on the cup. Then he peeled off the other sticker to seal the cup, and said, "Your prison number is J256-". "No!" I stopped him right away. "Yes! Your number, is... J256-" he yelled again. "No!" I stopped him once more. "That's not my number!" I said as he retorted, "Isn't your number... Uhmm J2-". "I know what my number is", I stated. "That's my cellmate's number! You dumb ass!" (Well, this last statement, I actually did not say, of course. I only thought it).

He had not bothered to read the label before calling my supervisor to send me back to my wing. Thinking about my recent encounter with the "Security Unit" and the cell number, he had assumed that the urine test was for me. His prejudice toward me had flown so naturally, like the urine I had provided for them. I grabbed the cup from his hand, opened the lid, and emptied my bodily fluids into the sink. Then I lifted up my boxers and I walked out of the restroom without saying a word. I did not have to say anything.

When we believe only the things we want to believe, we end up wrongfully judging and punishing others. Many times, we take action without actually knowing the true facts of a situation. Just because something may seem a certain way does not mean it is. Our prejudice gets in the way of wisdom, and we do not care to find out the facts, even when we have the facts in front of us, naked for everyone to see.

\section{ABOUT THE AUTHOR}

Victor Becerra is incarcerated in California. He can be contacted at:

Victor Becerra, K09324

CTF-Central

P.O. Box 689

Soledad, California 93960-0689

USA 